nature" had certainly influenced my thinking - and feeling-as a moral theologian. I could understand those people feeling imprisoned within a deformed body and seeking revenge on the world-such as Gloucester.

I flew back to England the next day as the trial continued. During the flight the young woman came to mind. Her mother had been in choking sobs during my testimony. I had articulated what her daughter could not. A certain sadness descended. It was one thing to write about an ear in the pages of this medical journal for a professional readership, or to speak to plastic surgeons, but to be examined in a court of law is altogether different. The woman's life would never be the same; and I formally announced the fact.

\section{Unexpected new doors}

When my first Personal View appeared I indicated how vulnerable it made me feel. The publication certainly affected my life. It opened unexpected new doors. Several professional friendships resulted. Receiving 36 letters, some written with painstaking, poignant details, and responding was rewarding. Testifying at a trial 4000 miles away was the most unexpected result. The conversations with the judge and the disfigured woman will remain with me for a long time. For all of these reasons the initial publication was worth the vulnerability in attempting to address Kierkegaard's "terrors of existence and their explanation."

\title{
Insulin and independence
}

\author{
JACK D EASTWOOD
}

Many diabetics seem to experience unnecessary anxiety and disturbance of their normal way of life owing to the difficulty that they find in correctly regulating their insulin dosage and to restrictions imposed on their diet. I have been a diabetic for 60 years and for the past 50 have employed a somewhat unorthodox method of treatment, which I adopted after nearly 10 years of intensive study, much of it experimental and all based on carefully documented observation of my own experience with insulin.

In brief summary, its distinctive feature is that I inject insulin at every mealtime and vary the dose according to the food eaten, instead of basing the treatment on a fixed dose of insulin each morning and then trying to adjust my diet, exercise, etc, to this throughout the next 12 or 24 hours.

\section{The first year}

I was one of the first to benefit from the discovery of insulin. My diabetes was diagnosed in 1925, when I was 13 years old. At that time I was very thin and small and had an inordinate thirst, and I doubt whether my parents needed any other warning signs than these, as the younger of my two elder brothers had died of diabetes six years previously, just before his 12th birthday, after being kept alive for some time by very great restrictions on his diet: the discovery of insulin was tragically too late from his point of view but just in time to save my life. I was taken to a Harley Street specialist and spent three weeks in a nursing home, during which time my diet and insulin requirements were settled. I returned home to be looked after by my parents in accordance with the detailed instructions given to them.

My diet was strictly controlled, especially on the carbohydrate side; for two years all my food was weighed, and no excesses at all were allowed. Much of my food consisted of specially manufactured sugar free brands, so that sugar was entirely replaced by saccharine; the necessary bulk was provided by large quantities of green vegetables. Subcutaneous injections of soluble insulin were given before breakfast and supper each day. I cannot remember exactly what the daily dose was in those earliest days, but I believe that it was about $20 \mathrm{U}$ with the carbohydrate content of my food amounting to about $25 \mathrm{~g}$.

At this stage my knowledge of what was going on was confined to a clear understanding of how important it was to keep to the rules, and to early recognition of the symptoms of an overdose of insulin; reactions of this kind were encouragingly few, and this first year was marked by a rapid and dramatic improvement in the state of my general health and development.

Skipton, North Yorkshire

JACK D EASTWOOD, MA, retired headmaster

Correspondence to: 4 Low Lane, Embsay, Skipton, North Yorkshire BD236SD.

\section{Early study: daily charts}

In 1926, at the age of 14, I won a scholarship to St Paul's School, and as that necessitated travelling to London by train daily and having lunch at an ordinary Lyons restaurant I felt the need to learn more for myself both about diabetes in general and about my own case in particular. I therefore began regularly doing my own insulin injections and urine tests and reading as much as I could on the subject, and it was not long before I was able with considerable accuracy to guess the weight of a normal helping of most of the commonest foodstuffs and to work out the carbohydrate, protein, and fat content of any meal that I ate, realising that it was essential for me to do this if I was ever going to have a meal in a restaurant or, indeed, anywhere other than at home.

This exercise, and the study both on general and on personal grounds that accompanied it, soon became so interesting to me that in March 1929 I decided to start keeping daily charts on which I systematically recorded a wide variety of facts and figures relevant to my life as a diabetic, including exact details of each injection, of the food eaten at every meal, and of the results of urine tests, which I did two or three times each day, together with comments and queries, which I added at the end of some of the more unusual weeks. I continued this practice for six years, almost without a break, and consider therefore that these charts may constitute one of the longest and most detailed diabetic histories in existence. The charts are still in my possession, and I would readily lend them to any responsible person who thinks that they might be of some help or interest to him.

\section{Experiments at Oxford}

In 1931 I went up to Oxford, having won a scholarship to New College, and it was during the next five years while I was there that I learnt most about diabetes and took the first steps towards the less orthodox but, I would submit, not less intelligent method of treatment that had become normal in my case by the time I left university.

I lived a full, normal, and happy life at Oxford for those five years. I usually had breakfast in my own room, consisting of about $65 \mathrm{~g}$ carbohydrate, $12 \mathrm{~g}$ protein, $25 \mathrm{~g}$ fat, and large quantities of green vegetables to make up the bulk which I still needed; these vegetables were, in fact, the only special request I had to make of the college kitchen staff. More often than not I had lunch at an ordinary restaurant (about $10 \mathrm{~g}$ carbohydrate, $40 \mathrm{~g}$ protein, $30 \mathrm{~g}$ fat, and again plenty of green vegetables), and nearly every afternoon I played golf and then had three or four cups of tea (with a little milk). On most evenings I had the normal four course dinner in hall, eating whatever foods were served in the quantities required to provide about $65 \mathrm{~g}$ carbohydrate, $35 \mathrm{~g}$ protein, and $30 \mathrm{~g}$ fat; the accuracy of these calculations I regularly checked by urine tests before going to bed each evening, and I found myself able to make them almost instinctively after about a year. Two insulin injections were given daily, one of $25 \mathrm{U} 30$ minutes before breakfast and one of $35 \mathrm{U} 45$ minutes before dinner. 


\section{The challenge of bad test results}

I should emphasise that the above are average figures, and that periodically I considered it advisable to vary my diet, and especially its carbohydrate content, quite drastically to avoid too many bad test results; full details of all these variations during my first three years at Oxford are recorded in the daily charts.

The period from May 1934 to June 1935 was a particularly interesting one. My general health remained as good as ever, but I found it difficult to keep the results of the tests right, and it would almost be true to say that I rarely succeeded in doing so without taking what I then regarded as unacceptably large quantities of insulin. This led to my starting the practice, which I have continued ever since, of regularly giving myself a small extra dose (about $8 \mathrm{U}$ ) after lunch, except when I was going to play golf in the afternoon-and often even then (in order to clear a bad one o'clock test). I also sometimes gave myself insulin immediately after, instead of before, breakfast or supper, or both, if the result of the test beforehand was very bad and I was getting desperate (for example, at not having had a clear result for a day or two). Not unnaturally, this was generally successful in achieving the immediate objective of a sugar free result.

The main features (mostly, as I now believe, bad) of my diet during those months were a large protein ration ( $170 \mathrm{~g}$ meat, for example, at both lunch and supper) and little carbohydrate (rarely more than $60 \mathrm{~g}$ in a day, and quite often less). I had enormous quantities of cheese (sometimes $110 \mathrm{~g}$ at both breakfast and supper, and perhaps another $60 \mathrm{~g}$ for lunch). At the same time my appetite was very large indeed, and for breakfast I usually had a very large quantity of greens $(230-280 \mathrm{~g})$. The proportion of fat in the diet was also doubtless too large for that of carbohydrate.

\section{Vacation exercise}

The maintained excellence of my general health, however, and particularly my experiences during the two holiday months immediately after my final exam in June 1935, confirmed my belief that I had no cause for serious anxiety. In July of that year I spent three weeks touring and golfing in Scotland and had almost normal food at all meals-that is, moderate amounts of protein, a great deal of carbohydrate, and rather a lot of fat. I did no tests at all, but frequently experienced quite severe symptoms of an overdose of insulin while playing golf in the mornings (in which case I ate large quantities of chocolate-as much as two or three bars, which, incidentally I found seemed to contain unexpectedly little carbohydrate), and the insulin in the morning soon came down to about $25 \mathrm{U}$ (carbohydrate for breakfast about $70 \mathrm{~g}$ ). In the evening the insulin was usually about $35 \mathrm{U}$ with a high carbohydrate meal (50-60 g) following, and I sometimes needed even more carbohydrate at 10 or $11 \mathrm{pm}$. Moreover, no insulin was required in the middle of the day (I always played golf both morning and afternoon), and I was able to have about $25 \mathrm{~g}$ carbohydrate for lunch, together with eggs, tomatoes, and large quantities of cheese.

A little later, during the last two weeks in August while staying with my sister on a farm in Cornwall, I had a still more normal diet, even to the extent of regularly having an ordinary picnic lunch (sandwiches-about $80 \mathrm{~g}$ carbohydrate-and hardly anything else). An average day's arrangements were: 30 U 20 minutes before 50-60 g carbohydrate, bacon and eggs, tea; short walk and bathe in morning; then $15 \mathrm{U}$ immediately before an $80 \mathrm{~g}$ carbohydrate lunch; four or five mile walk in the afternoon; two cups of tea; and $35 \mathrm{U} 20$ minutes before a normal dinner (including 50-60 g carbohydrate). During this fortnight I tested only three or four times, usually at 7 pm, and usually got perfect results.

Finally, while staying with friends for another fortnight in September I again followed this practice of having ordinary meals (including lunch, after which I gave myself 10-18 U). The average daily insulin dose was $85 \mathrm{U}$, and the carbohydrate about $140 \mathrm{~g}$. The total quantity of food was certainly much less than during the previous three years, and I did not do any tests.

These three experimental periods all pointed clearly to the advantage of including a fairly high carbohydrate ration in my diet. I therefore decided at the beginning of my last year at Oxford to return to this policy and pursue it more resolutely in future, with a more or less normal diet, and to carry out urine tests only when I had reason to think the result might be bad.

\section{Lessons from Oxford}

Some may consider that this change of tactics and attitude entailed an unwarrantable risk and that I was lucky not to suffer in consequence of it, but I disagree, because not only was it the result of carefully planned experiments but I had also already learnt from experience that worry is extremely bad for diabetics, and I fully appreciated the danger in my own case of the watchfulness with which I had looked after my health for so long developing into an obsession; to become a hypochondriac would, I was sure, have a much more harmful effect on my diabetes than the reasoned change of tactics to which most of my experience seemed so clearly to point.

These were indeed two of the most important lessons that I had learnt very thoroughly by the time I came down from Oxford: firstly, the highly beneficial effect of physical exercise on my carbohydrate tolerance; secondly, on the other hand, the harmful effect of worry or emotional disturbance of any kind. I had been warned about the effect of exercise at an early stage of my diabetic life but learnt about the effect of worry only from experience, and it took me two or three years to learn the full extent of both the benefit and the harm, respectively. An afternoon's golf or tennis, for example, meant that I could reduce the preceding insulin dose, or increase the carbohydrate content of the previous meal, by as much as $40 \%$ without affecting the result of the next urine test, whereas serious mental anxiety usually resulted in bad test results however much I altered the amount of insulin or carbohydrate.

The third lesson concerned the importance, in judging the significance of the result of any urine test, of noting the period covered by the sample tested. In the case of most tests this period (the period that has elapsed since the previous passing of water) is of several hours' duration, especially overnight, but I found that even after a very bad early morning result there was quite often no trace of sugar in the "fresh" urine passed (naturally in small quantities) only 15 minutes later. Even more frequently, after a bad result at $1130 \mathrm{pm}$ (five hours after an injection) there was no trace of sugar at $730 \mathrm{am}$ next morning ( 13 hours after the same injection), especially when the test was carried out on fresh urine.

These occasions, and similar experiments with fresh urine tested at other times of the day, all suggested that the insulin did not work fully until many hours after it had been injected and confirmed my belief in the value of as long an interval as possible between injection and meal; they also strengthened my already growing view that the seriousness of isolated bad test results should not be exaggerated.

\section{A normal life}

In 1935 I visited the specialist for the last time: at the end of the visit he said that he thought there was no need for me to go and see him again, because by then I knew more about controlling my own diabetes than he did, and I remember hearing this verdict with a strange mixture of pride, humility, and gratitude. I consider that his confidence and my optimism at that time have been fully justified by the rest of my life story so far.

I am now 74 . In 1972 I retired at the age of 60 , after teaching for 36 years and having consistently followed the policy of doing an injection at every mealtime - the average daily dose amounting to about $65 \mathrm{U}$-and of eating almost anything I wanted, giving myself either just before or just after every meal the amount of insulin that I knew from experience would be needed to cope with the food about to be eaten or just eaten, due allowance being made for what I expected to be doing during the next few hours.

Many doctors have described this to me as the nearest approach they have ever met to nature's method of treating diabetes, and some modern research suggests that the success that I have had in controlling my diabetes by frequent injections may well be partly responsible also for the freedom from complications that I have now enjoyed for 60 years. Once or twice I have wondered whether it would be sensible to switch from soluble insulin to the more recently developed slow acting type, or to a combination of both types, but on each occasion I have decided that there is no point in disturbing a system that works so exceptionally well; the only change of this kind that I did make was to start using double strength (soluble) insulin in about 1940, and I have used that ever since until the recent compulsory switch to U100.

For my last 25 years as a teacher I was headmaster of three well known schools, and throughout my 36 years of teaching I was absent from school for only nine days (three because of a sprained ankle and two because of a fractured rib), and I played an active part in the life of all the schools in which I worked and all the communities in which I lived. My only reason for mentioning this is to emphasise that my diabetes interfered with none of it, and that $I$ have not in fact so far had to face any diabetic crises or complications of any kind.

I find it interesting to reflect that my "near to nature" method of treatment has meant that I have done over 50000 injections (nearly all of them in the calf) since I first started, but I can truthfully say that this has been no more than a minor inconvenience. It takes me only about 30 seconds to do an injection, and I once did one on the top of a London bus without any of the other passengers noticing. It has in fact become so much a matter of habit that I occasionally find it difficult to remember whether I have done one or not, but, fortunately, on the rare occasions on which I actually have missed one through forgetfulness I have been made unmistakably aware of this within three or four hours by the pronounced drowsiness and unusual thirst that in my case always occur when I have taken insufficient insulin. 


\section{Living down a bad reputation}

Although I realise that there are different types of diabetes and that each case must be treated separately and according to expert advice, my experience leads me to wonder whether this kind of treatment, which I have used successfully for so long, is being used today as often as it should be, because it seems to me to be so reasonable. Its main advantage is that by spreading the intake of insulin more evenly over each 24 hour period and therefore injecting it in smaller doses the patient can more easily maintain a stable blood sugar level and enjoy a flexible lifestyle free from any complications associated with poor control. In this respect it seems indeed to have something in common with many of the most recent developments in treatment, such as infusion pumps, button infusers, Penjects, and the like.

It is also my opinion that, given a sound understanding of the nature of diabetes and a clear recognition of the powerful effect of insulin, the following are the only other essential requirements for its successful use:

(1) A knowledge of at least the carbohydrate content of different foodstuffs.
(2) The ability to assess how much insulin is needed in one's own case to deal with any given quantity of carbohydrate.

(3) A willingness to check the accuracy of one's judgment in these matters by urine or blood tests, carried out three or four times a day during the early learning stage and at longer, varying intervals thereafter according to circumstances.

(4) The ability to recognise in good time the symptoms of an overdose of insulin.

(5) A generally disciplined way of life.

The first of these requirements is quite easy for any reasonably intelligent person to satisfy; the second needs careful study and is greatly helped by experience; the third is just a matter of common sense; the fourth is no more difficult than recognising when one has had enough alcohol to drink; and the last is not a bad rule for anyone, whether diabetic or not. It is also worth remembering that all of these requirements are, if not necessary, at least highly desirable for the successful control of diabetes by any kind of treatment.

Diabetes today is surely one of the least disabling of all disabilities; it just has a bad reputation to live down, and I shall be very happy if my story can contribute to that end.

\section{Life in the Lutyens household}

\section{MARY LUTYENS}

As the only survivor of Edwin Lutyens's five children I was honoured last February with an invitation to the opening of the new BMA library by HRH The Princess of Wales. I went in some trepidation since I have seen quite a few unhappy alterations to my father's buildings. But all was more than well. His Great Hall had, both architecturally and decoratively, been converted with great sensitivity. The architect was Mr Ivan Nellist of Nellist, Blundell, and Flint, and the conversion was undertaken by the firm of V A T Watkins.

I was secretly amused to see that the colour of the columns happened to be the exact shade of blue very dear to Theosophists in 1911 when my father was commissioned by Mrs Annie Besant, president of the Theosophical Society, to build a new headquarters for the society. At that time most Theosophists believed in the near coming of the world teacher, the Lord Maitreya, and that an Indian boy of 15 , Jiddu Krishnamurti, had already been chosen to be the vehicle whose body the Lord Maitreya would occupy when he came. It was said that he had previously occupied the bodies of Sri Krishna and Jesus. The blue of the new library's columns was the exact colour of the Lord Maitreya's aura, seen on the astral plane by the same clairvoyant Theosophist as had chosen Krishnamurti.

After Mrs Besant (who also claimed clairvoyance) had laid the foundation stone of the building she wrote in the Theosophist of November 1911:

\footnotetext{
"Mighty presences graciously grouped themselves above the stone, One of Whom will often be seen hereafter in this place He blessed when He takes the body a-preparing for Him. ... The walls will echo to the musice of $\mathrm{His}$ voice."
}

\section{London W9 1BN}

MARY LUTYENS

Correspondence to: 8 Elizabeth Close, Randolph Avenue, London W9 1BN.

\section{Crisis building}

The building was the cause of a near crisis in my parents' marriage. My mother had become a Theosophist in 1910 and it was through her that my father had met Mrs Besant and received his

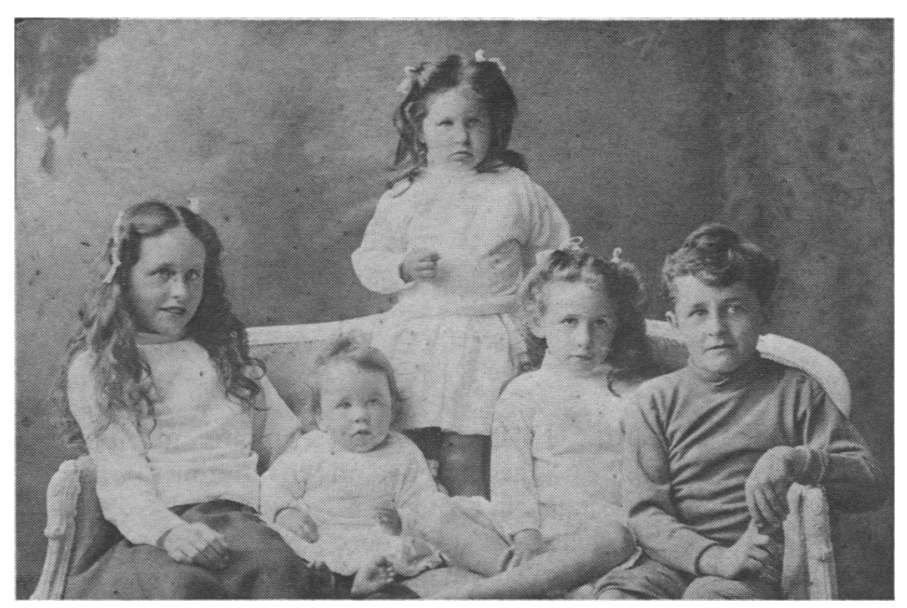

From left to right, Barbara, Mary, Elisabeth, Ursula, and Robert Lutyens. About 1909.

commission. The original estimate for the building was $£ 50000$. By 1914 that figure had doubled after Mrs Besant had twice changed her mind about the flat that she wanted on the top floor, had sacked the clerk of works my father had chosen, without seeking his permission, and had insisted on employing only union labour. While she was in India working for Indian Home Rule, Dr (afterwards 